Скрябін О.Л., кандидат історичних наук, провідний науковий співробітник науководослідного відділу науково-дослідного ичентру воєнної історії НУО Украӥни імені Івана Черняховського (м. Київ);

Щипанський П.В., кандидат військових наук, професор, заступник начальника університету з наукової роботи НУО України імені Івана Черняховського (м. Київ)

\title{
ПОЛТАВСЬКИЙ КАДЕТСЬКИЙ КОРПУС - ПЕРШИЙ ВІЙСЬКОВИЙ НАВЧАЛЬНИЙ ЗАКЛАД НА ТЕРЕНАХ УКРАЇНИ: ДО 180-РІЧЧЯ СТВОРЕННЯ
}

У статті висвітлено історію створення $і$ діяльність найстарішого військового навчального закладу на теренах Украйни - Полтавського кадетського корпусу. Розповідається про роль держави $і$ украйнського дворянства у створенні навчального закладу. Розглянуто основні віхи розвитку навчального закладу: у формі кадетського корпусу $i$ військової гімназії. Проаналізовано підготовку вихованців закладу через ї̈ три основні блоки загальноосвітній, військовий $і$ виховний. Показано, щэо на фоні суворого армійського побуту, в якому постійно перебували юнаки, помітна увага приділялася їх вихованню.

Ключові слова: Полтава, дворянство, кадетський корпус, військова гімназія, кадети, загальноосвітня підготовка, військова підготовка, виховна робота.

Залишається забутою подія відкриття 6 грудня 1840 року першого військового навчального закладу на теренах України - Полтавського кадетського корпусу, який заклав початкові засади підготовки професійних військових кадрів на українській землі. Можна стверджувати, що у 2020 році 
виповниться 180 років не лише цьому навчальному закладу, а й початку військової освіти на теренах України.

Отже, метою статті $є$ висвітлення історії створення та діяльності першого військового навчального закладу в Україні для врахування особливостей цього досвіду в сучасних умовах удосконалення військової освіти.

Очевидним $є$ те, що створення закладів освіти не обійшлося без втручання держави. Національна політика царизму завжди була спрямована на пошук ефективних механізмів залучення місцевих еліт до будівництва імперії та їі збройних сил. Своєрідною апробацією такого механізму були дії царського уряду щодо народів Кавказу, коли малолітніх дітей гірських князів примусово відправляли в Санкт-Петербург на виховання саме в кадетських корпусах [1, с. 192-193].

На теренах України російська влада також активно вживала заходи, націлені на злам національного розвитку та орієнтацію дворянства на служіння імперії. 3 цією метою влада підтримувала установи, які мобілізували освіту та культуру в інтересах русифікації [2, с. 69]. Політика щодо українських еліт була більш м'якою і дітей примусово не віддаляли від родин, проте бажання забезпечити своїм нащадкам гарну освіту, дати їм можливість зробити військову кар'єру змушувало українське дворянство об’єднувати фінансові можливості на створення відповідної інфраструктури військово-навчального закладу.

Змістову характеристику дворянства України дав у своїх спогадах М. Домонтович, який отримав освіту у Полтавському кадетському корпусі і став одним із перших його випускників. Він згадував: “Проживаючи у глухих помістях і займаючись сільським господарством, дворянство не залишало станового честолюбства. Воно, як молода аристократія, дуже чуттєво відносилось до своєї шляхетності і будь-якими заходами намагалось його зміцнювати і підтримувати. “Намагайтесь навчатись добре, щоб служити i 
дослужуватись", такий був клич середнього і особливо дрібного місцевого дворянства напередодні відкриття Полтавського корпусу” [3, с. 447-448].

Царська влада на кадетську освіту покладала завдання: “надати російському дворянству пристойне виховання, навчити їх всьому, що у військовому званні потрібно знати, зробити їх здатними з користю і честю служити государю, добробут всього життя покласти на непохитну прихильність престолу" [4, с. 22-23]. Отже, першочерговим завданням військової освіти керівництво держави вважало виховання відданих престолу офіцерів.

Заснувати кадетський корпус у Полтаві було вирішено в 1836 році в рамках державної програми створення губернських кадетських корпусів. У наказі Миколи I від 5 квітня 1836 року проглядається спроба готувати майбутніх офіцерів на історичних традиціях: “Назначив учредить в Полтаве кадетский корпус и желая, чтобы сие полезное учреждение служило памятником знаменитой победы, одержанной под Полтавой Петром I, повелеваю: корпус сей именовать Петровско-Полтавским и день учреждения оного праздновать в день победы 27 июня, дабы и воспитывающиеся в заведении молодые дворяне, готовясь на поприще военное вспоминали о той славе, какую стяжали их предки на полях полтавских" $[5$, с. 8].

Місце для розташування корпусу було обрано особисто Миколою I під час його перебування у Полтаві. Комісію по нагляду за будівництвом очолив місцевий генерал-губернатор князь М. Репнін, а старшим архітектором було призначено М. Бонч-Бруєвича. Будівництво корпусу коштувало понад 2,6 млн рублів - величезну для тих часів суму. До корпусу були приписані дворянські сім'ї чотирьох губерній - Полтавської, Чернігівської, Катеринославської та Слобідсько-Української (Харківської).

6 грудня 1840 року Петровсько-Полтавський корпус було відкрито. Цей день став корпусним святом, а день Полтавської битви, 27 червня - храмовим $[6$, c. 26,32]. Цей кадетський корпус став першим військовим навчальним закладом на території України. 
Першим директором кадетського корпусу було призначено генералмайора В. Святловського, який до цього служив у Першому Московському корпусі. Його погляди на виховання кадета можна з'ясувати в наказах по корпусу [7, с. 7]. В одному 3 них він зазначав: “Ви, діти, готуючись до військового поприща, завчасно повинні звикати і засвоювати обов'язки воїна. Ваш зовнішній вигляд, постава, хода повинні мати військовий відбиток. Благородство душі, чистота вдач, твердість характеру, любов до неухильного виконання свого обов'язку, прихильність до Батьківщини, покора начальству, боязнь Божа повинні бути вашими внутрішніми якостями" [6, c. 32].

Штат корпусу було встановлено в 400 осіб, спершу набрали лише один підготовчий клас із дітей дворян тих губерній, що брали участь у заснуванні навчального закладу, а вже через чотири роки корпус було укомплектовано повністю [6, с. 26, 32]. Приймалися до нього юнаки віком від 10 до 18 років.

У 40-х роках ХІХ-го століття повний курс кадетської освіти був восьмирічним і складався з трьох відділів: підготовчого (2 роки), загального (4 роки) та спеціального (2 роки). У 1857 році у корпусі були введені спеціальні класи, де кадети здобували кінцеву освіту i направлялися прапорщиками в піхоту, інженерні війська, а також у батальйони внутрішньої варти [6, с. 81]. Проіснували такі класи в Полтавському кадетському корпусі до 1862 року. Упродовж 1858-1862 років заклад випустив 130 офіцерів $[7$, c. 8$]$.

У 1865 році під час військових реформ корус був перетворений на військову гімназію, що надавала юнакам лише підготовчу військову освіту, яку вони продовжували здобувати у військовому училищі. Проте вже в 1882 році знову було відновлено кадетський корпус 3 посиленням його військової спрямованості. У наказі по корпусу відмічалося: “перейменування не $є$ лише зміною назви. Кадет $\epsilon$ військове звання, що вимагає особливих якостей, необов'язкових для учнів інших відомств. Для гімназиста обов'язково пройти відомий курс, для кадета, крім навчальної програми, - 
засвоїти засади військового виховання" [6, с. 173]. Випускники корпусу, як і у попередній період, по закінченню закладу переводилися до військових училищ. У 1890 році було урочисто відсвятковано 50-річний ювілей навчального закладу. За цей час Полтавський кадетський корпус (військову гімназію) закінчило 1975 осіб.

Більшовицький переворот і визвольні змагання 1917-1921 рр. стали останньою віхою історії Полтавського кадетського корпусу. У ці роки навчальний заклад неодноразово змінював назву, його закривали, a вихованців розпускали по домівках. Важливо зауважити, що для боротьби 3 більшовиками в часи загрози захоплення ними Полтави вихованці корпусу завжди приєднувалися до вояків Армії Української Народної Республіки $[8$, c. 95$]$.

Розпорядженням Ради Народних комісарів УРСР від 12 лютого 1919 року корпус було закрито. Проте особовий склад закладу ще до захоплення міста Червоною армією разом із військами збройних сил Півдня Росії переїхав до Владикавказу, де об’єднався 3 місцевим кадетським корпусом. Навесні 1920 року вихованців корпусу евакуювали до Криму, а після загальної поразки Білого руху вони емігрували за кордон.

Як зазначено вище, діяльність цього навчального закладу виділяється за напрямами підготовки кадетів: загальноосвітнім, військовим та виховним.

Загальний термін навчання в корпусі періодично змінювався. До запровадження спеціальних класів кадети навчалися шість років, а після їх введення - вісім. У військовій гімназії був встановлений шестирічний курс навчання, однак у 1873-1874 навчальному році заклад перейшов на семирічний курс, по одному року в кожному класі $[9$, с. 54]. Саме семирічний курс навчання залишився в Полтавському корпусі до кінця його існування. Навчальний процес регламентувався “Статутом для військово-навчальних закладів", який визначав функціонування навчальної, виховної, фронтової частин навчального закладу [10, с. 6-8]. 
У корпусі наприкінці 1850-х років викладали такі загальні дисципліни: Закон Божий, російська, французька i німецька мови, чистописання i малювання, математика (арифметика, тригонометрія, геометрія, алгебра), географія, законознавство, фізика, ботаніка 3 зоологією, малювання (креслення) [11, арк. 24-25]. На спеціальному курсі вивчали: Закон Божий, мови, історію, законознавство, математику та хімію. Додавалося вивчення статистики і низки військових дисциплін [12, арк. 18-19; 13, арк. 14-16].

У військово-гімназійний період навчальна програма стала винятково загальноосвітньою. Часу, що відводився на викладання низки дисциплін, було достатньо, щоб надати вихованцю глибокі знання 3 точних та гуманітарних дисциплін. Кількість щотижневого навчального часу, що відводився на освоєння учнем математичних наук (5,5 год), закладала фундамент у засвоєння точності і логіки, необхідних військовій людині в умовах розвитку озброєння та військової техніки. Значна увага приділялася викладанню російської (4,3 год) та іноземних мов (4 год), що сприяло оволодінню мистецтвом слова у спілкуванні з різними верствами суспільства $[14$, c. 5$]$.

Створений у гімназійний період навчальний план майже без суттєвих змін ще два десятиріччя зберігався і в кадетських корпусах. У розподіл часу на окремі предмети періодично вносилися зміни залежно від розвитку педагогічної науки та військової справи.

Уваги заслуговує досвід підбору викладачів. У перші роки до викладання залучалися вчителі з інших відомств, як правило, 3 місцевих навчальних закладів. Так, 3 місцевої гімназії до викладання залучалися: Бодянський - математика [15, арк. 1-2], Поппело-Давидов - природничі науки [16, арк. 1-2], а Соссе - французька мова [17, арк. 1-2]. Щоб зацікавити кращі кадри до роботи з кадетами, військове відомство збільшило вчителям грошове утримання і дало змогу безкоштовно навчатися в корпусі їхнім дітям. Одночасно з цим зросли і вимоги до підбору кадрів [18, с. 231]. За задумом керівництва викладачі мали володіти не лише знаннями та 
методикою викладання своєї навчальної дисципліни, а й розуміти психологію особи, яка з раннього віку потрапила в сувору для неї військову атмосферу.

Дослідник історії корпусу І. Павловський зазначав, що “за винятком викладачів іноземної мови, всі вони отримали вищу освіту в Харківському університеті, який був розсадником для нашого закладу” [6, с. 49]. Серед викладачів корпусу було чимало діячів науки й культури, громадських діячів. У різні часи тут працювали: директором - учений математик, автор наукових праць і підручників з арифметики, геометрії, тригонометрії і педагогіки Ф. Сімашко, члени Кирило-Мефодіївського товариства В. Бєлозерський i Д. Пильчиков, а також історик-архівіст І. Павловський, художник-портретист I. Зайцев та інші [19, с. 758].

Процесу військової підготовки кадетів у повній мірі сприяла атмосфера, яка панувала у корпусі. Його вихованець О. Бутковський згадував: “Усі ми були оточені лише військовим елементом. Сама атмосфера відпрацьовувала в нас ультрастройові інстинкти" [20, с. 330-331].

У перші двадцять років діяльності закладу військовий елемент був головним у підготовці кадетів, а його основою вважалася стройова підготовка, яку називали “фронтовим навчанням”. Нею займалися не менше 6 годин на тиждень й стільки ж часу відводилося на фехтування і гімнастику [6, с. 29]. У спеціальних класах основи військової справи закладалися під час засвоєння курсів $з$ артилерії, фортифікації, тактики та військової топографії [21, с. 69]. Кадети усіх вікових груп були розділені на роти, що об'єднувалися в батальйон.

Під час гімназійного періоду спеціальні дисципліни були перенесені до військових училищ. Керівний документ - "Положение о военных гимназиях" - визначав зміст військової підготовки дуже лаконічно: "Вихованці навчаються гімнастиці, виправці, маршируванню i піхотним сигналам" [22, с. 135]. Основою військової підготовки юнаків стала гімнастика.

За загальним розкладом на стройові заняття протягом тижня було визначено для молодшого віку - 2 години, для вихованців старшого віку - по 
1 годині. Навчання проводилося поетапно, спочатку одиночна підготовка, потім стройові прийоми у складі відділення. Для зменшення кількості стройових занять вихователі протягом дня слідкували, щоб вихованці рухались у складі підрозділів стройовим кроком під час пересувань.

У літньому таборі військові заняття проводилися за таким же порядком. Першокласники вчилися пересуватися бігом під удар барабана, починаючи 3 другого класу - поодиноким стройовим прийомам, потім рядами та шеренгами і закінчували маршируванням у складі відділення. Піхотним сигналам вчили попередньо на голос, за допомогою вчителя співу [23, с. 592-593]. У 70-х роках ХІХ століття на військові вправи у літній табірний час почали звертати уваги ще менше, а сам табір поступово перестав бути для гімназистів місцем військової практики.

У другий кадетський період до внутрішнього порядку навчального закладу повернули військовий характер. Кадетів знову розподілили по ротах за віком. Перша рота, до складу якої входили 7 та 6 класи, вважалася стройовою [24, с. 257-259]. Протягом навчального року військова підготовка кадетів включала в себе стройові заняття, гімнастику, фехтування. У таборі заняття розподілялися на практичні (стройові навчання, військові прогулянки, вогнева підготовка, топографічні роботи) та теоретичні (ознайомлення 3 відомостями, обов'язковими для кожного солдата та топографічне креслення) [25, с. 7-9].

Теоретичні знання кадети могли застосовувати на практиці. Для цього були введені військові прогулянки, що навчали їх стійко переносити труднощі військового життя. У середніх класах кадети читали триверстну карту і орієнтувалися на місцевості, знали азбуку Морзе, проводили розвідку на місцевості, знали інженерні споруди саперного містечка [26, арк. 8-9]. Юнаків знайомили з господарською та побутовою сторонами військового життя - як влаштовувати вогнища, готувати їжу, надавати допомогу при нещасних випадках, влаштовувати казарми, обслуговувати коней, шити 
чоботи тощо. Отже, навчання в корпусі сприяло формуванню в них навичок військової справи.

Головною метою виховання була підготовка майбутніх офіцерів до служби шляхом поступового формування у кадетів 3 дитячого віку світогляду, основним підгрунтям якого були відданість престолу, свідома покора владі і закону [10, с. 23]. Його засобами були дотримання розпорядку дня, продуктивне наповнення позакласного часу, постійний нагляд над вихованцями та підтримання у них дисципліни [28, с. 10]. Головна увага керівництва навчального закладу приділялася підтриманню військової дисципліни та порядку.

У перші десятиріччя існування закладу виховні прийоми були примітивними і зводилися до прищеплення учням почуття страху за будь-які порушення через покарання, серед яких широко практикувалися тілесні. Це призвело до значої кількості порушень дисципліни, насамперед проявів неповаги до старших. Найбільш резонансним виглядав кадетський бунт 1860 року, коли кадети відмовилися виконувати накази своїх командирів i директора закладу. Спроби керівництва швидко навести порядок призвели до масових безладів. Даний випадок показує наскільки низьким був рівень організації виховної роботи. Результати перевірок Головного управління військово-навчальних закладів підтвердили незадовільний стан військової дисципліни у корпусі [7, с. 89-90].

На виправлення такого стану керівництво закладу витрачало чимало сил вже за часів військової гімназії. Вживалися різноманітні заходи попереджувального та виправного характеру, але новизною стало те, що вихователі вже намагалися не карати, а оберігати юнаків від вчинків, використовуючи заходи педагогічного впливу. Ось витяг із засідання Педагогічного комітету, що характеризує загальні погляди його членів: “Досвід показав, що і найбільшого пустуна не слід вважати невиправним. Нерідко його молода натура, віддавши данину віком, змінюється на краще. У такий момент безпідставне стягнення може подіяти на неї вкрай шкідливо, 
охолоджуючи в вихованці бажання виправити свою репутацію” $[29$, c. $76-77]$.

Важливу роль у розбудові кадетської освіти відіграв один із кращих керівників закладу генерал-лейтенант Ф. Сімашко, який скасував принизливі покарання, - звичай ставити в кут, заносити прізвище вихованця на чорну дошку, обмежувати в їжі. Звичайно, навіть найбільш правильні педагогічні дії керівництва не могли припинити типові дитячі пустощі, але серйозних проблем дисциплінарного характеру, таких як бунти 60-х років XIX століття, вже не виникало.

Щоб продуктивно наповнити позакласний час, було введено позакласне читання книжок. Групові читання завжди супроводжувалися поясненнями та повчальними бесідами вихователів. Варто сказати, що читання пригодницької літератури іноді шкодило вихованцям. Так, у 1875 році два вихованці Полтавської військової гімназії відправилися до Америки, але добравшись до Кременчука вирішили повернутися [30, с. 152154].

3 метою культурного розвитку кадети регулярно відвідували місцеві театри, музеї, виставки, концерти. У закладі проводили розважальні вечори, програма яких включала читання поетичних творів, хоровий спів, виконання музичних п’єс, танці, вистави. Місцеві кадети влаштовували спектаклі на військові сюжети - “Карл XII під Полтавою”, “Ветеран і новобранець” тощо [7, с. 62]. Обов’язково гралися попурі з українських пісень. І цікаво, що українські народні пісні кадети виконували під керівництвом обрусілого німця - капітана К.Ф.Фон-Касарта, шанувальника музики й пісні, а особливою популярністю у його вихованців користувалася пісня “Закувала та сива зозуля" [31, с. 11].

Любов кадетів до музики і співу підтверджують спогади вихованця П. Волошина. Він згадував: “Ми могли співати досить складні музичні твори, що i робили на концертах, які позитивно вражали гостей. У річницю Полтавської битви весь особовий склад, розташований на парадних сходах, 
заспівав дуже важку для виконання кантату, написану в старовинних ладах українською мовою” [32, с. 13].

Традиційно у корпусі значна увага приділялася вивченню історії рідного краю. Регулярно влаштовувалися походи та екскурсії по історичних і культурних місцях Полтавщини (наприклад, піші екскурсії в Диканьку) [31, с. 11]. Вищезгаданий П. Волошин, перебуваючи в еміграції, через пів століття ностальгічно згадував: "У многих из нас были томики "Кобзаря" (запрещенного в гимназиях). Мы были тронуты судьбой бедной “Наймички”, Палия, ушедшего в иноки. Пели с волнением и очень стройно “Як умру, то поховайте мене на могилі...”, инстинктивно чувствуя в стихах большую любовь к родному краю” [32, с. 11]. Таке відношення до творів національної культури пояснюється українським походженням великої кількості наставників із числа офіцерів-вихователів і особливо викладачів, які позитивно ставилися до місцевої культури та побуту. Саме завдяки їхній лояльності національний вплив на виховання кадетів хоча й непослідовно, але мав місце в цьому закладі.

Традиційно в корпусі був високим рівень військово-патріотичного виховання юнаків. Вірність присязі, військовому обов’язку, традиціям виховувались у корпусі з першого дня перебування вихованця в установі.

Окремої уваги заслуговує шана до військової традиції корпусного святкування - 6 грудня. Наскільки міцно ії шанували кадети можна судити по прикладу, наведеному П. Волошиним. Він згадував: “На святкування прибували колишні випускники і кадети дуже часто бачили дивну картину, коли розтовстілі поміщики, які давно забули в своїх Кобиляках та Сорочинцях про марширування, повинні були формувати для проходження строєм два або три взводи, а старший з колишніх кадет, ними командував. У 1906 році при святкуванні дня кадетського корпусу старшим виявився вікарний єпископ. Коли йому запропонували під час параду стати поруч 3 директором він відповів: “Ні! Традиція - є традиція. Буду командувати 
взводом. Адже Апостол Павло був солдатом!”. I він з блиском, елегантно, вибудував взвод і чудово промарширував перед директором" [33, с. 6].

Розглядаючи діяльність закладу в хронологічних межах, доцільно згадати і про тих, хто там навчався: багато героїв Кримської (1853-1856рр.), російсько-турецької (1877-1878рр.), російсько-японської (1904-1905рр.) та Першої світової (1914-1918рр.) війн. Близько ста вихованців - учасники російсько-турецької війни, які проявили доблесть, визволяючи Болгарію. Під час російсько-японської війни приклад самовідданості показав герой оборони Порт-Артура, інженер, полковник С. Рашевський. Інший учасник цієї війни офіцер-артилерист О. Пащенко став героєм битви під Ташичао (1904 р.). Там він застосував стрільбу з гармат із закритих позицій, ставши піонером у цій справі.

Високий рівень підготовки в корпусі підтверджується тим, що багато вихованців згодом стали директорами кадетських корпусів. Так, Першим Московським корпусом керували В. Римський-Корсаков i Давидов, Київським - М. Попруженко, Одеським - М. Дерюгін, Псковським - І. Боголюбов, Суворовським - А. Ваулін, а С. Саранчов очолював в різні часи корпуси у Полоцьку і Сумах [34, с. 77].

У корпусі навчалися відомі митці: видатний художник М. Ярошенко, художник-пейзажист М. Холодовський, композитор М. Казанлі, один із піонерів повітроплавання В. Сльяшевич, автор численних наукових праць із педагогіки О. Бутовський, електротехнік і метеоролог Ф. Величко [31, с. 17].

Варто констатувати, що навчання в Полтавському кадетському корпусі сприяло вирішенню завдань загальної підготовки юнаків, формуванню в них навичок військової справи. Навчальний заклад давав юнакам гарну для тих часів освіту та виховання, що забезпечувало їм майбутнє як на військовому, так і цивільному теренах. Водночас діяльність закладу була підпорядкована цілковито військовим інтересам царизму. Відправлення хлопчика в корпус безповоротно виривало його 3 рідного національного самобутнього середовища, замінюючи його суворим армійським побутом. Через сім років 
кадетського і два роки юнкерського життя він виростав у бравого парубка, який з гордістю говорив про себе: “Я офіцер”. Почуття любові до рідної землі, яка дала йому життя, залишалося лише спогадом дитинства.

\section{Список використаних джерел і літератури}

1. Мельницкой Н. Сборник сведений о военно-учебных заведениях в России. - С.Петербург, 1857. - Т. II. ч. 3. - 225 с.

2. Шандра В.С. Українські суспільні інститути у взаєминах із Російським самодержавством / В. С. Шандра // Український історичний журнал. - К., 2010. - № 4. - С. 59-82.

3. Домонтович М.A. Полтавский кадетський корпус в первые годы его существования // Исторический вестник. - СПб, 1890. - Т.42. - ноябрь. C. 444-476.

4. Петров П.В. Главное управление военно-учебных заведений. 1802-1902. Исторический очерк / П.В.Петров., Н.А.Соколов. - СПб., 1907. ч. II. - 163 с. (Столетие военного министерства; т. 10).

5. Полное собрание законов Российской империи. Собрание второе. 1825 - 1881. - Т.11. - №8751 / Об именовании учреждаемого в городе Полтаве Кадетского корпуса Петровским-Полтавским. С. 8.

6. Павловский И.Ф. Исторический очерк Петровского Полтавского кадетского корпуса (1840-1890) / И.Ф.Павловский. - Полтава, 1890. - 183 с.

7. На память прежним и нынешним воспитанникам ПетровскогоПолтавского кадетського корпуса. 1840-1890 // Педагогический сборник. СПб., 1891. - № 1. - С. 1-15.

8. Омельянович-Павленко М. Спогади командира (1917-1920). - К. : Темпора, 2007. - $608 \mathrm{c}$.

9. Петров П.В. Главное управление военно-учебных заведений. 1802-1902. Исторический очерк / П.В.Петров., Н.А.Соколов. - СПб., 1914. ч. III. -215 c. 
10. Положение о кадетских корпусах // Педагогический сборник. СПб., 1886. - № 9. - С. 1-73.

11. Центральний державний історичний архів України (далі - ЦДІАУ), ф. 707, оп. 23, спр. 502, 29 арк.

12. ЦДІАУ, ф. 707, оп. 25, спр. 468, 24 арк.

13. Державний архів м. Києва (далі - ДАК), ф. 112, оп. 1, спр. 284, 26 арк.

14. Общая программа и инструкция для преподавания учебных предметов в военных гимназиях и однородных с ними заведениях // Педагогический сборник. - СПб., 1883. - № 1. - с. 1-42.

15. ЦДІАУ, ф. 707, оп. 7, спр. 281, 2 арк.

16. ЦДІАУ, ф. 707, оп. 22, спр. 391, 7 арк.

17. ЦДІАУ, ф. 707, оп. 13, спр. 154, 2 арк.

18. Мельницкой Н. Сборник сведений о военно-учебных заведениях в России. - С.Петербург, 1860 - т. IV. ч. 6. - 451 с.

19. Полтавщина : Енциклопедичний довідник / За редакцією Кудрицького А.В.). - К., 1992. - 1024 с.

20. Бутовский А.Д. Годы моего ученья в Петровском Полтавском кадетском корпусе // Педагогический сборник. Кн. 11. - Петроград, 1915. C. $315-337$.

21. Лалаев М.С. Исторический очерк военно-учебных заведений, подведомственных Главному их Управлению: 1700 - 1880. - СПб., 1880. $464 \mathrm{c}$.

22. Полное собрание законов Российской империи. Собрание второе. 1825-1881. - Т. 41. - №43738 / Высочайше утвержденное Положение о военных гимназиях. С. 132-141.

23. Материалы, извлеченные из протоколов военных гимназий за 1867 год.// Педагогический сборник. - СПб., 1868. - № 2. - С. 590-810.

24. Военная энциклопедия. - Петербург, 1913. - Т. ХІ. - 680 с. 
25. Инструкция для военно-подготовительных занятий в кадетских корпусах.// Педагогический сборник. - СПб., 1888. - № 7. - С. 3-18.

26. ДАК, ф. 112, оп. 3, спр. 39, 18 арк.

27. Завадский Н.П. Владимирский Киевский кадетский корпус. 1851 10/XII 1901 г.: Исторический очерк / Н. П.Завадский. - К. : Типография Р.К.Лубковского, 1908. - 145 с.

28. Инструкция по воспитательной части для военных гимназий, однородных с ними заведений и военных прогимназий // Педагогический сборник. - СПб., 1882. - № 1. - С. 1-70.

29. Материалы, извлеченные из протоколов педагогических комитетов и годовых отчетов военных гимназий за 1863 - 1868 года. // Педагогический сборник. - СПб., 1868. - № 1. - С. 50-367.

30. Алпатов Н.И. Учебно-воспитательная работа в дореволюционной школе интернатного типа: Из опыта кадетских корпусов и военных гимназий в России / Н. И. Алпатов - М. : Изд. Учпедгиз, 1958. - 310 с.

31. Жук В.Н. Один з цікавих навчальних закладів минулих часів (Петровський Полтавський кадетський корпус) / В. Н. Жук. - Полтава, 1993. $-23 \mathrm{c}$.

32. Волошин П. Три времени в четырех стенах // Военная быль. Париж, 1959. - № 34. - С. 10-15.

33. Волошин П. Три времени в четырех стенах // Военная быль. Париж, 1959. - № 36. - С. 5-8.

34. Гурковский В.А. Кадетские корпуса Российской империи. Кн. 2 / В. А. Гурковский. - М. : Белый берег, 2005 - 367 с. 
Scriabin O.L., Candidate of Historical Sciences, Leading Researcher of Research Division of Research Centre of Military History of Ivan Cherniakhovskyi National Defense University of Ukraine (Kyiv);

Shchypanskyi P.V., Candidate of Military Sciences, Professor, Deputy Chief of Ivan Cherniakhovskyi National Defense University of Ukraine (Kyiv)

\section{THE POLTAVA CADET CORPS - FIRST MILITARY EDUCATIONAL INSTITUTION IN THE TERRITORY OF UKRAINE: UP TO 180 YEARS OF CREATION}

The article deals with the history of creation and activity of the oldest military educational institution in the territory of Ukraine - Poltava cadet corps. The role of the state and the Ukrainian nobility in the establishment of the school is told. The main milestones of the educational institution's development are analyzed: in the form of a cadet corps and a military gymnasium. The analysis of preparation of the pupils of the institution through its three main blocks - general, military and educational is given. It is shown that against the background of a strict army life, in which young men were constantly housed, particular attention was paid to their national upbringing.

Keywords: Poltava, nobility, cadet corps, military gymnasium, cadets, general training, military training, educational work. 